\title{
12
}

\section{Mansiri in North Sulawesi: A new dentate-stamped pottery site in Island Southeast Asia}

\author{
Naszrullah Azis, Christian Reepmeyer, Geoffrey Clark, Sriwigati \\ and Daud A. Tanudirjo
}

\begin{abstract}
This report outlines new results from the Mansiri site, close to Toraut village, in North Sulawesi. A series of small excavations in 2015 recovered red-slipped pottery with decorations including dentate stamping, most commonly in straight or curved lines, circle impression and red painting including horizontal lines sometimes associated with dentate-stamped borders. These are decorative similarities shared with middle Lapita assemblages from the southwest Pacific, but the Mansiri assemblage also shows notable differences from the highly ornate Lapita pottery. Initial radiocarbon dating from the excavation shows evidence of a possible pre-3000 BP deposit at the site.
\end{abstract}

Keywords: North Sulawesi, Neolithic dating, Neolithic pottery, red slipping, dentate stamping

\section{Introduction}

Early Neolithic open sites in Island Southeast Asia (ISEA) are exceptionally rare with only around 20 sites dated to $3000 \mathrm{cal} \mathrm{BP}$ or older, and several have significant disturbance leading to doubt about the association of their cultural deposits with an early Austronesian occupation (Spriggs 2003, 2007, 2011). Despite decades of archaeological research, it remains unclear whether conclusive ceramic evidence has been recovered for a direct connection between the Lapita culture in the West Pacific and any Neolithic culture in ISEA, although there are claims to the contrary (Hung et al. 2011; Spriggs 2011; Carson and Kurashina 2012). Recently, Specht et al. (2014), in 'deconstructing' the Lapita Cultural Complex in the Bismarck Archipelago, noted the absence of an ancestral 'homeland' for the distinctive Lapita dentate-stamped pottery. Nonetheless, eastern Indonesia and the north coast of New Guinea were likely routes through which population movement occurred during the Neolithic, but these areas have received only modest amounts of archaeological research.

In this paper, we report a new site containing dentate-stamped, circle impressed, red-slipped and red-painted pottery in North Sulawesi. The small amount of decorated pottery at Mansiri parallels some of the techniques and designs identified in Lapita and ISEA assemblages, but Mansiri also contains vessel forms that have not been identified in any Lapita assemblage. The initial 
and tentative dating of Mansiri indicates the beginning of the ceramic phaseat the site around 3300-2700 cal BP and the ceramics might represent two-way movement between ISEA and the West Pacific after the initial occurrence of Far Western Lapita in the Bismarck Archipelago (Denham et al. 2012; Specht et al. 2014). This hypothesis would also support the simultaneous westward transportation of Kutau/Bao obsidian from New Britain in the Bismarck Archipelago, as seen in Neolithic levels of Bukit Tengkorak, Sabah, at around 3200-2900 cal BP (Bellwood and Koon 1989; Chia 2003) and its occurrence on Cebu, Philippines (Reepmeyer et al. 2011), albeit undated.

\section{Location}

The Mansiri site $\left(0^{\circ} 32^{\prime} 42^{\prime \prime} \mathrm{N} 123^{\circ} 52^{\prime} 3^{\prime \prime} \mathrm{E}\right)$ is in the Bogani Nani Wartabone National Park, Bolaang Mongondow District of North Sulawesi, approximately $50 \mathrm{~km}$ west of Kotamobagu City (Figure 12.1). Situated in an upland region of North Sulawesi, the site location follows a similar settlement pattern to sites in the Karama Valley in Western Sulawesi (Anggraeni et al. 2014), being associated with a main inland river system. The closest distance to the sea is to the south, $25 \mathrm{~km}$ in straight line. The large river system of the Sungai Dumoga, however, drains in a west-east direction from the Central Mountains of North Sulawesi to the northeast, where it meets the sea at the Lombagin village, approximately $60 \mathrm{~km}$ away. The Mansiri site is located at 273 metres above sea level ( $\mathrm{m}$ asl) at the western end of the Dumoga valley in the foothills of the Central Mountain range. The site experiences an equatorial climate and used to be covered by tropical rainforest. Unfortunately, in recent times, the area has been subject to uncontrolled logging and forest clearing and is now used as farmland for sweet corn agriculture.

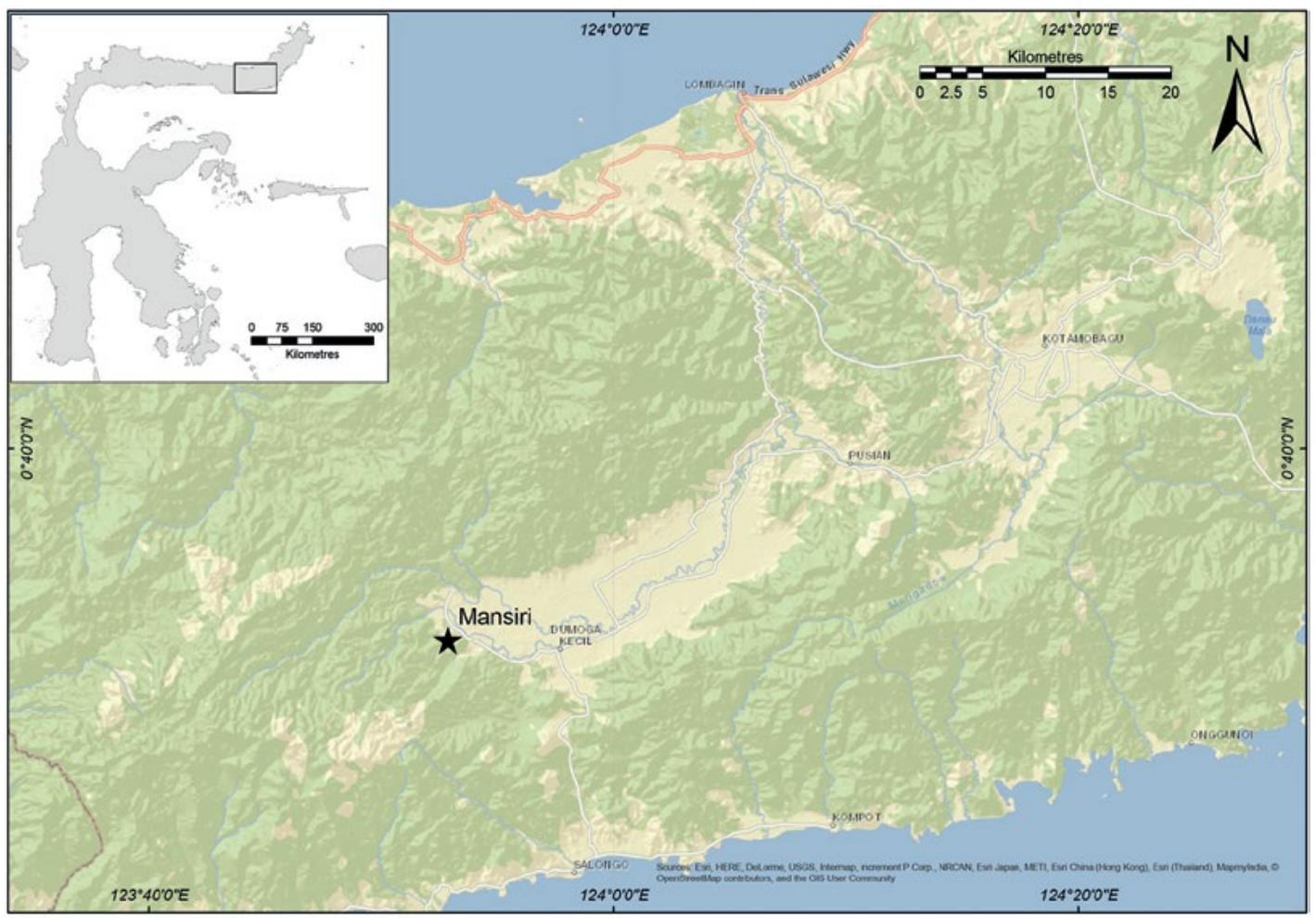

Figure 12.1: Map of the location of Mansiri site.

Source: Manado Archaeology Office. 


\section{Survey and excavation}

Initially discovered during survey activities in the early 1990s by Dr Joko Siswanto of the Manado Archaeology Office, the Mansiri site had not been a focus of archaeological activities until a revisit to the area by the Manado Archaeology Office in 2011, and a surface survey of the surrounding area detected additional artefactual material. Previous excavations conducted by the Manado Archaeology Office in 2011-13 uncovered large numbers of decorated ceramic sherds indicative of an early Neolithic site.

Fieldwork in 2015 was conducted on 13 days between the 9-12 of April (Figure 12.2). During this time, activities included excavation of four test pits (Trenches A-D) and a north-south auger test drilling transect (16 samples, spaced at $2 \mathrm{~m}$, total length of $32 \mathrm{~m}$ ), to identify the extent of the site, as well as digital mapping of the general topography of the area (Figure 12.3).

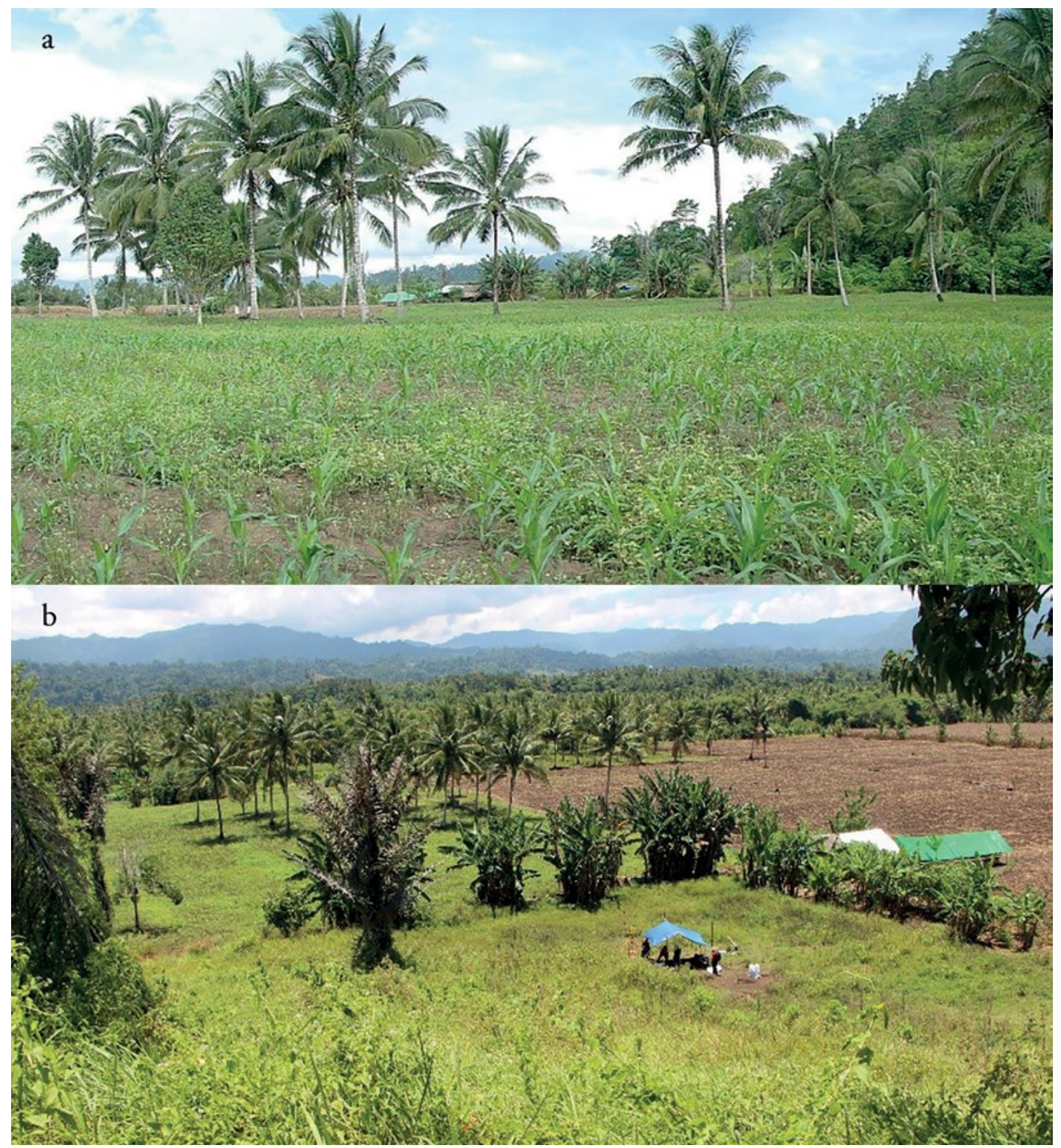

Figure 12.2: (a) Panorama (facing north) of the site and (b) location at the foot of hill slope. Source: Christian Reepmeyer. 


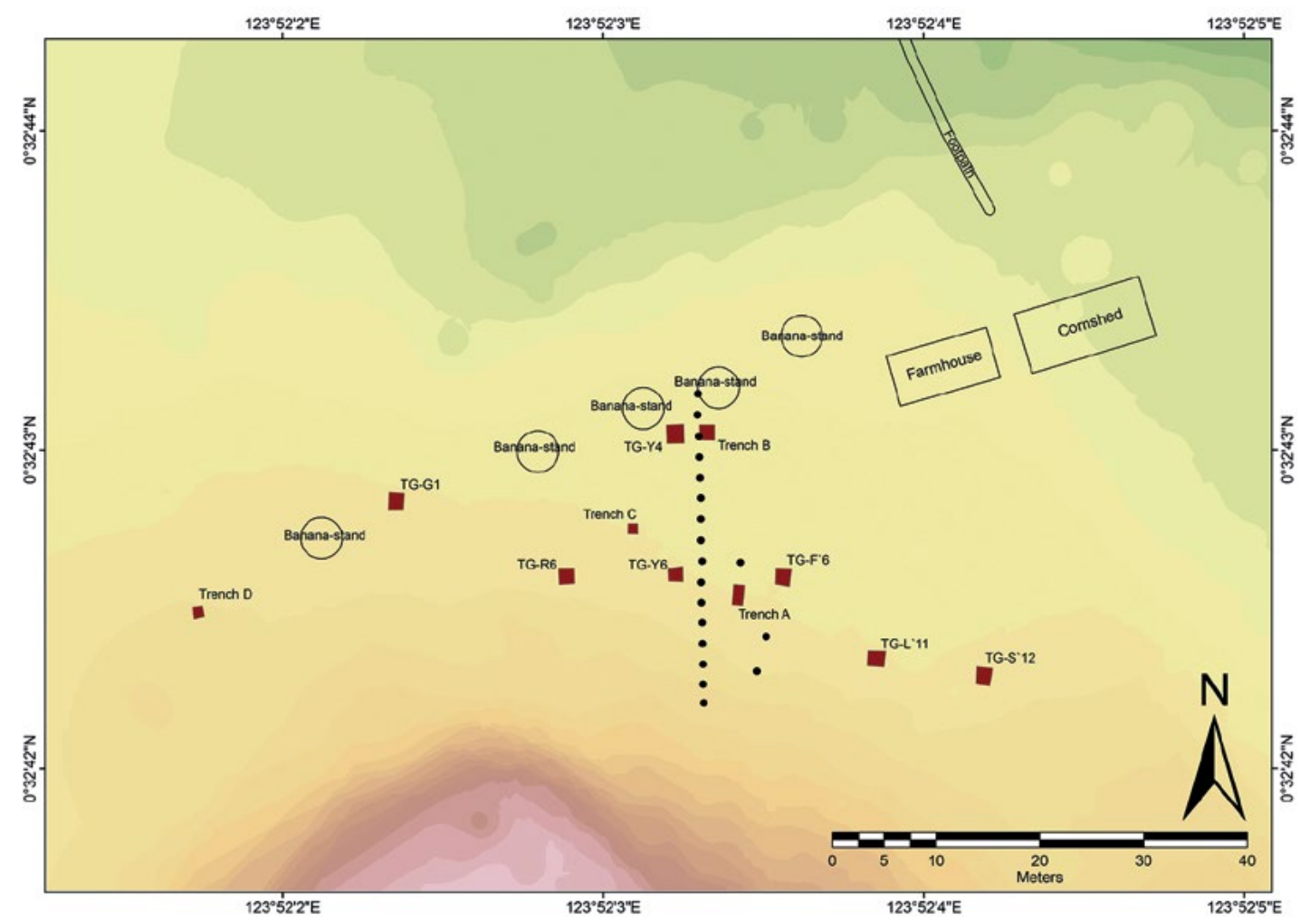

Figure 12.3: Digital elevation (green colour represents low areas and lavender high areas) and site plan of the Mansiri site with the location of previous excavation by Balai Arkeologi Manado (TG-G1 to TG-S'12) and 2015 excavations (Trenches A-D).

Source: Christian Reepmeyer.

The Mansiri site is an elevated, relatively level area of approximately $100 \mathrm{~m}$ x $40 \mathrm{~m}$ extent, situated to the south of an old creek bed (now dry) on a gentle rise. Currently, the area is only used for intermittent cattle grazing, with no sweet corn planted on the site location. Artefact density in prior excavations of the Manado office was found to be highest in the central area and to decline significantly to the north (Trench TG-G1) and east (TG-S`12). The northern boundary of the site is demarcated by an old creek bed and large banana stands; however, pottery was found in all of the auger drill holes to the north, indicating that the site extent most likely reaches still further north. The southern border is the steeper part of the slope of a hill that rises to about $400 \mathrm{~m}$ asl. It appears that the southern site boundary does not extend further up the hill slope as indicated by the lack of artefactual material in the southern auger drill holes and the lack of artefacts or structures on the hill top. Significant erosion is occurring due to logging/burning of vegetation on the hill slope. 


\section{Trenches $\mathrm{A}, \mathrm{C}$ and $\mathrm{D}^{1}$}

Trench A (Figure 12.4) is a $1 \mathrm{~m} \times 2 \mathrm{~m}$ excavation in north-south alignment, whereas both Trenches $\mathrm{C}$ and $\mathrm{D}$ were $1 \mathrm{mx} 1 \mathrm{~m}$ test units to the north of the site. The deposit was excavated in natural (stratigraphic) layers, or arbitrary $10 \mathrm{~cm}$ units if finer stratigraphic units could not be detected during digging, until a sterile layer was reached at $\sim 160 \mathrm{~cm}$ (Table 12.1).
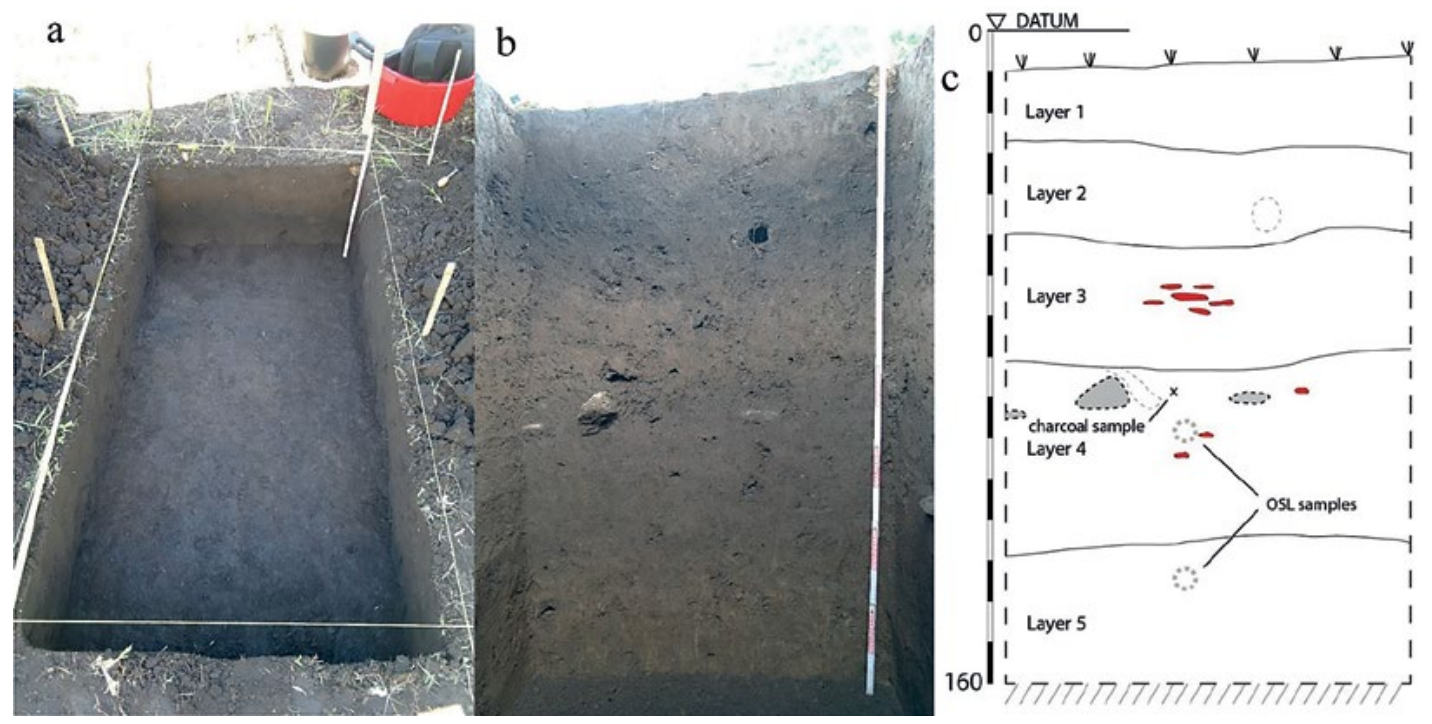

Figure 12.4: Trench A in plan (a) and section (b) view of the south section. Section drawing (c) of the south section of Trench A.

Source: Christian Reepmeyer.

Table 12.1: Stratigraphy of Trenches $\mathrm{A}$ and $\mathrm{C}$ at Mansiri.

\begin{tabular}{|l|l|}
\hline Layer $1(5-27 \mathrm{~cm}$ UD): & Topsoil, lighter brown sandy silt with frequent tree roots. Some rat burrows. \\
\hline Layer $2(27-50 \mathrm{~cm}$ uD): & $\begin{array}{l}\text { Topsoil, very humic, loose, dark sandy silt, loamy. Some large rat burrows. } \\
\text { Frequent tree roots. }\end{array}$ \\
\hline Layer $\mathbf{3}(50 \mathrm{~cm}-80 \mathrm{~cm}$ uD): & $\begin{array}{l}\text { Lighter grey-brown sandy silt. Some tree roots. One pottery concentration, most likely } \\
\text { 16th century. Some rat burrows. }\end{array}$ \\
\hline Layer $\mathbf{4}(80 \mathrm{~cm}-125 \mathrm{~cm}$ uD): & $\begin{array}{l}\text { Main cultural layer until } 102 \mathrm{~cm} \text { uD. Below } 105 \mathrm{~cm} \text { only rarely ceramics. Grey (slightly } \\
\text { darker than Layer 3) sandy silt with some clay content. Rare rat burrows and other } \\
\text { bioturbations (mainly in top part of layer). }\end{array}$ \\
\hline Layer $\mathbf{5}(125 \mathrm{~cm}-160 \mathrm{~cm}$ uD): & $\begin{array}{l}\text { Sterile yellow-brown mottled soil. Medium sand with some clay content. Most likely } \\
\text { top part of weathered bedrock. }\end{array}$ \\
\hline
\end{tabular}

Note: uD = under Datum.

Source: Excavators' field notes.

\section{Trench B}

Trench B (Figure 12.5) is located around $10 \mathrm{~m}$ to the north of Trench A and in the same alignment as TG-Y 4 trench excavated in 2014 by the lead author and his team. Trench dimensions were $1.5 \mathrm{~m} \mathrm{x} 1.5 \mathrm{~m}$ to a maximum depth of $210 \mathrm{~cm}$ where either bedrock or a terrace of large water-rolled boulders was reached (Table 12.2). The trench was excavated in $10 \mathrm{~cm}$ units below $100 \mathrm{~cm}$. The top $100 \mathrm{~cm}$ were excavated in one unit by shovel.

1 Trench D shows the same stratigraphic sequence as Trenches A and C, but is slightly deeper. The radiocarbon date at $143 \mathrm{~cm}$ is associated with the main cultural Layer 4 , as described in Table 12.1. 


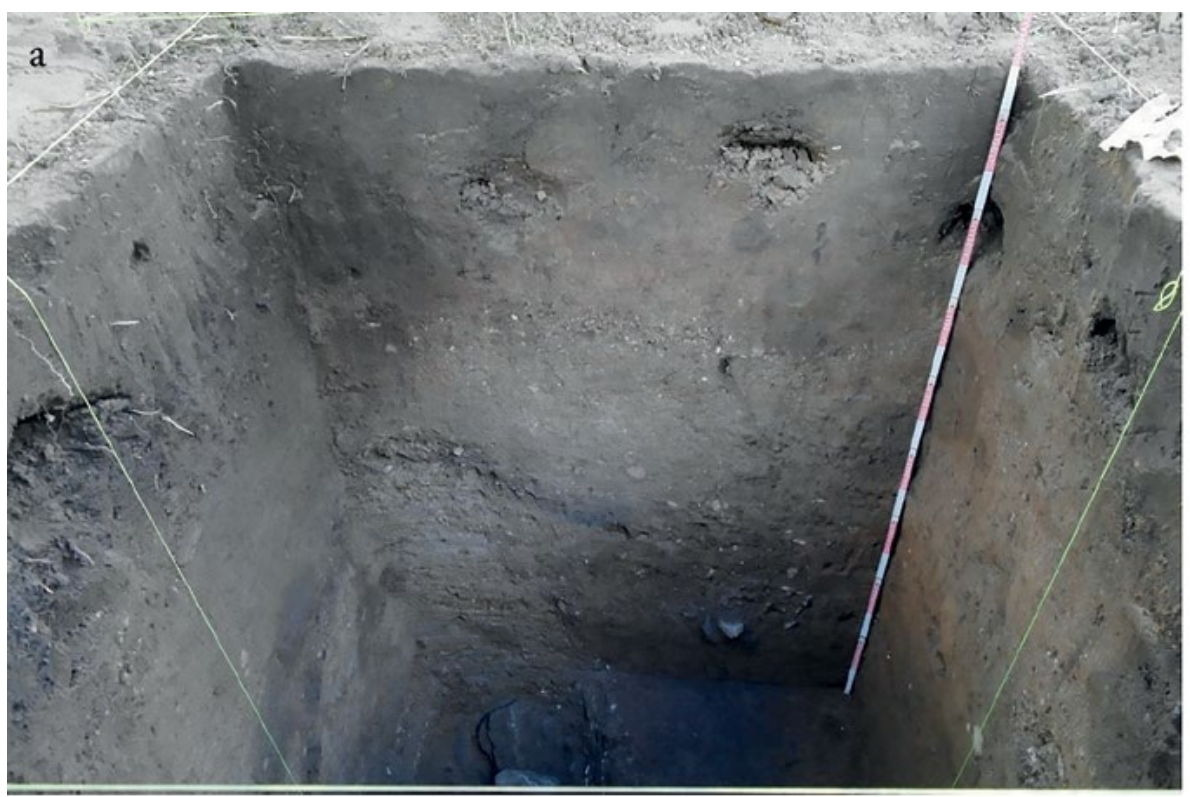

b

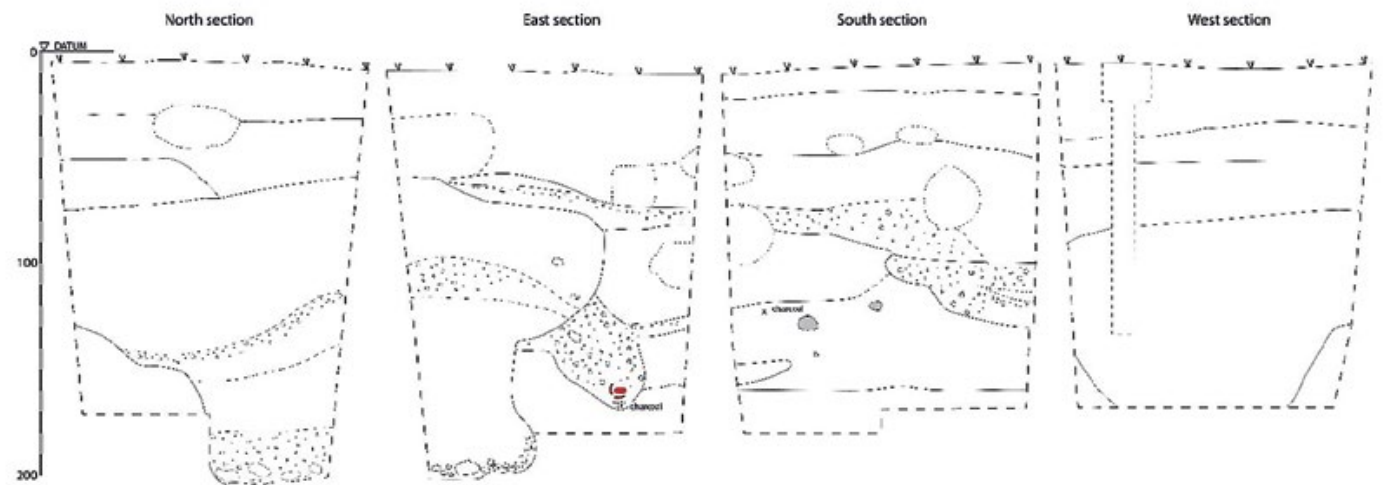

Figure 12.5: (a) View of east section of Trench B, drainage channel in the northern part, which cuts through cultural layers at around $180 \mathrm{~cm}$; (b) Section drawing of all sections of Trench B.

Source: Christian Reepmeyer.

Table 12.2: Stratigraphy of Trench B at Mansiri.

\begin{tabular}{|c|c|}
\hline Layer $1(10 \mathrm{~cm}-25 \mathrm{~cm}$ uD): & Topsoil, light grey humic silt. Frequent rat burrows and tree roots. \\
\hline Layer $2(25 \mathrm{~cm}-55 \mathrm{~cm} u \mathrm{u})$ : & Topsoil. Dark grey humic soil. Frequent roots and bioturbation, relatively loose material. \\
\hline Layer $3 a(55 \mathrm{~cm}-65 \mathrm{~cm} u D)$ : & $\begin{array}{l}\text { Compacted grey silt with clay content. Frequent eroded gravel and white specks, } \\
\text { most likely weathered dolomite (or sandstone) pieces. }\end{array}$ \\
\hline Layer $3 \mathrm{~b}(65 \mathrm{~cm}-\sim 80 \mathrm{~cm}$ uD): & $\begin{array}{l}\text { Compacted grey silt, sandy with frequent angular or river-rounded gravel. } \\
\text { Weathered white specks continue. }\end{array}$ \\
\hline Layer 4 (80 cm - $200 \mathrm{~cm}$ uD): & $\begin{array}{l}\text { Sandy layer. Frequent river-rolled gravel. Relative soft material in the top part. } \\
\text { Alternating between finer sand layers and compacted gravelly sand. In the lower } \\
\text { part increasingly banded, frequent iron and black layered concretions. To the sides } \\
\text { particularly in the base part gravelly, mostly rounded. This layer cuts through all } \\
\text { subsequent layers. In the base of the layer large boulders, some angular and some } \\
\text { river-rolled. Frequently eroded sandstone gravel. There is a clear border between this } \\
\text { layer and the silt/clay layers to the south. Most likely old drainage channel. }\end{array}$ \\
\hline Layer 5 (85 cm - $127 \mathrm{~cm}$ uD): & $\begin{array}{l}\text { Very compacted silt/clay layer. Light grey-brown. Frequent burned tree roots. A large } \\
\text { moist patch (east section) appears to be an old tree root. }\end{array}$ \\
\hline
\end{tabular}




\begin{tabular}{|l|l|}
\hline Layer $6(127 \mathrm{~cm}-168 \mathrm{~cm}$ uD): & $\begin{array}{l}\text { Very compacted silty sand with frequent river-rolled gravel. Larger pieces of rock, } \\
\text { partly angular. Frequent pottery, main layer with cultural material. Only specks of } \\
\text { charcoal, most likely from only small tree roots. Frequent iron concretions. }\end{array}$ \\
\hline Layer 7 (135 cm - $160 \mathrm{~cm}$ uD): & $\begin{array}{l}\text { Very compacted grey-brown silt/clay with frequent white specks (weathered dolomite } \\
\text { or sandstone?). Mottled with some fine sand content. }\end{array}$ \\
\hline Layer 8 (below $160 \mathrm{~cm}$ uD): & Sterile compacted mottled yellow-brown silt. \\
\hline
\end{tabular}

Note: $u D$ = under Datum.

Source: Excavators' field notes.

Trench B shows significant disturbance from a drainage channel that cut through earlier deposits, including pottery-containing layers. It appears that these drainage channels are not recent as there is a substantial amount of sediment accumulated $(-70 \mathrm{~cm})$ on top of them. Ceramics were found in a pit feature filled with compacted silt/fine sand deposit with some clay content; the southern boundary of this pit feature is unclear. The sediment is concreted by iron aggregations. Charcoal samples were collected from the pit feature (unfortunately, these samples might have been contaminated by tree root disturbances) and the surrounding sediment.

\section{Results}

\section{Stratigraphy and age}

Only a limited amount of bioturbation (specifically, rats burrows) could be detected, which might have brought in sediment from higher layers. One charcoal sample recovered from the upper part of the pottery layer dates to 3355-3084 cal BP, while two additional samples from Trenches A (in the highest sections of the ceramic layer that might overlie the ceramic deposition) and D (in direct association with ceramic) showed slightly younger ages of 2720-2480 cal BP and 2720-2430 cal BP, respectively (Table 12.3 and Figure 12.4). Charcoal was scarce in the highly acidic soil, limiting the potential for radiocarbon dating of the site and encouraging the use of alternative dating methods.

Table 12.3: Summary of radiocarbon dates from Mansiri Trench TG7'6, Trenches A and D.

\begin{tabular}{|l|l|r|r|r|r|r|}
\hline \multicolumn{2}{|l|}{ Radiocarbon Date } \\
\hline Lab. code \# & Trench & $\begin{array}{c}\text { Burial depth } \\
\text { (cm) }\end{array}$ & \multicolumn{1}{c|}{ d13C } & D14C & ${ }^{14}$ C age & cal BP (95.4\%) \\
\hline S-ANU 400311 & TG-F'6 & $90-100$ & $-28.58 \pm 1.0$ & $-314.6 \pm 2.6$ & $3035 \pm 35$ & $3355-3084$ \\
Wk446052 & A1 & $80-90$ & $-28.0 \pm 0.4$ & $-266.9 \pm 1.8$ & $2494 \pm 20$ & $2720-2480$ \\
Wk446102 & D & 143 & $-26.7 \pm 0.4$ & $-264.6 \pm 1.8$ & $2469 \pm 20$ & $2720-2430$ \\
\hline
\end{tabular}

Sources:

1. ANU Radiocarbon Dating Centre. For experimental setup, see Fallon et al. (2010).

2. Waikato Radiocarbon Dating Laboratories.

It was decided to employ Optical Stimulated Luminescence (OSL) dating at the Oxford University Luminescence Dating Laboratory to investigate the radiocarbon ages. OSL results are based on luminescence measurements of sand-sized quartz $(180-255 \mu \mathrm{m})$ extracted from the samples using standard preparation techniques including, wet sieving, $\mathrm{HCl}(10 \%)$ treatment to remove carbonates, HF treatment (48\%) to dissolve feldspathic minerals and heavy mineral separation with sodium polytungstate. Measurements were performed in an automated luminescence reader (Risø DA15 upgraded to Risø DA20) made by Risø (Bøtter-Jensen 1988, 1997; Bøtter-Jensen et al. 2000) using a SAR post-IR blue OSL measurement protocol (Murray and Wintle 2000; Banerjee et al. 2001; Wintle and Murray 2006). A preheat combination of $220^{\circ} \mathrm{C}$ for the main OSL signal 
and $200^{\circ} \mathrm{C}$ for the test dose signal were adopted following the outcome of a dose recovery test on four of the samples (X6836 - X6839). Dose rate calculations are based on Aitken (1985) and are derived from the concentration of radioactive elements (potassium, thorium and uranium) within the samples. These were derived from elemental analysis by ICP-MS/AES using a fusion sample preparation technique. The final OSL age estimates include an additional $4 \%$ systematic error to account for uncertainties in source calibration and measurement reproducibility. These incorporated beta attenuation factors (Mejdahl 1979), dose rate conversion factors (Guérin et al. 2011) and an absorption coefficient for the water content (Zimmerman 1971). The contribution of cosmic radiation to the total dose rate was calculated as a function of latitude, altitude, burial depth and average over-burden density based on data by Prescott and Hutton (1994).

Unfortunately, OSL dating of the sediments resulted in anomalous dating of the pottery layer to a maximum of $1400 \mathrm{BP}$ with underlying sterile deposition at a maximum of approximately $2900 \mathrm{BP}$ (Table 12.4). At this stage, the discrepancy between the radiocarbon and OSL dates is unexplained; however, it is possible that this either evidences significant disturbances of sediment deposition or that water content in the sediment resulted in incomplete bleaching, degrading the accuracy of the OSL readings from the site (Murray and Olley 2002; Rhodes 2011). Furthermore, sampling of sediment cores for OSL dating was not ideal, as only improvised sampling containers (PVC pipe with $7 \mathrm{~cm}$ diameter, cut into $25 \mathrm{~cm}$ long sections) were used.

Table 12.4: Summary of OSL dates from Mansiri Trench A.

\begin{tabular}{|l|r|r|r|c|c|}
\hline OSL Dates & \multicolumn{1}{|c|}{$\begin{array}{c}\text { Lab. code \# } \\
\text { Xurial depth } \\
\text { (cm) }\end{array}$} & $\begin{array}{c}\text { Water content } \\
(\%)\end{array}$ & $\begin{array}{c}\text { Palaeodose } \\
\text { (Gy) }\end{array}$ & $\begin{array}{c}\text { Dose rate } \\
\text { (Gy/ka) }\end{array}$ & $\begin{array}{c}\text { OSL age estimate } \\
\text { (years before 2015) }\end{array}$ \\
\hline X6839 & 98 & 18.87 & $1.27 \pm 0.17$ & $0.98 \pm 0.07$ & $1290 \pm 195$ \\
\hline X6841 & 135 & 21.39 & $2.94 \pm 0.38$ & $1.21 \pm 0.09$ & $2430 \pm 380$ \\
\hline
\end{tabular}

Source: Oxford University Luminescence Dating Laboratory.

\section{Pottery}

In total, 2146 pottery fragments were excavated in 2015. Due to the high acidic content of the soil, the pottery is poorly preserved and highly fragmented, making the pot forms difficult to reconstruct. Identified pot forms include small flat bottom dishes, ring-foot dishes and globular pots with everted and thickened rims (Figures 12.6 and 12.7).

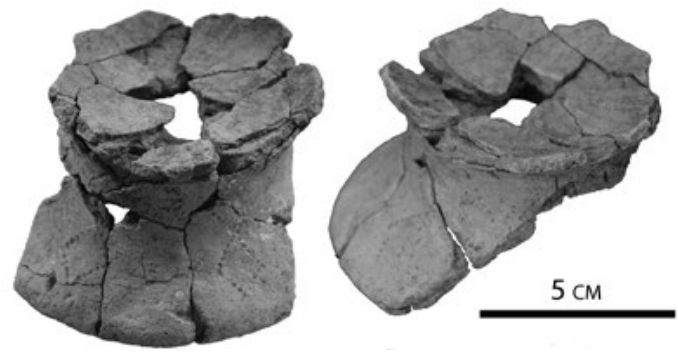

Figure 12.6: Example of a dentate-stamped ring-foot stand.

Source: Naszrullah Azis.

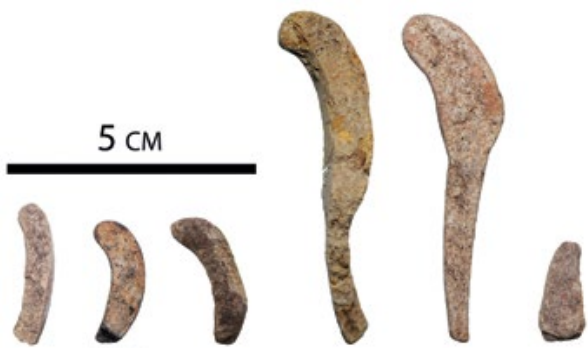

Figure 12.7: Examples of rim shapes. Source: Christian Reepmeyer. 


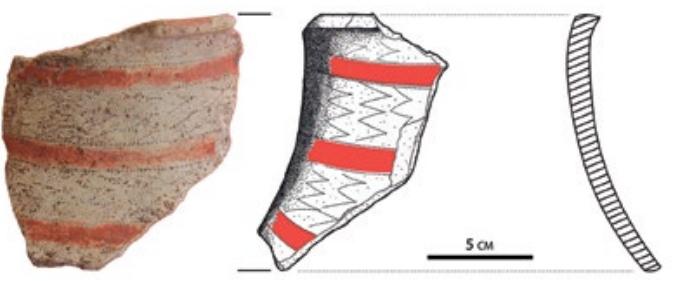

Figure 12.8: Selected example of red-painted and dentate-stamp decorated ceramic.

Source: Naszrullah Azis.
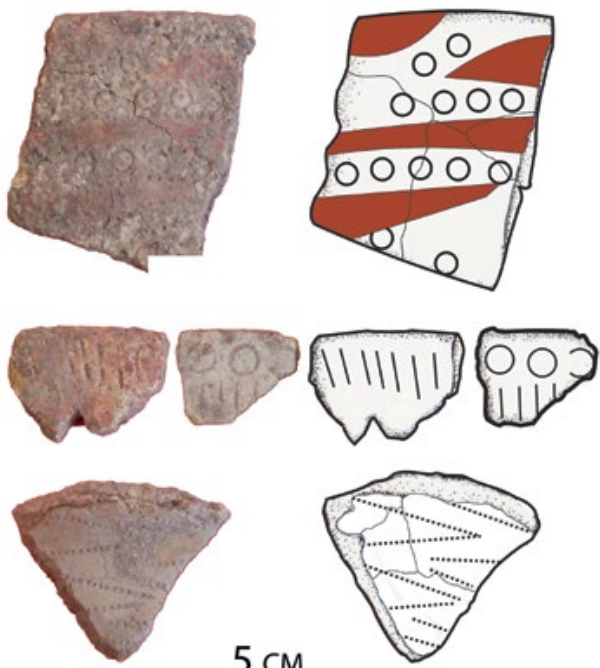

$5 \mathrm{~cm}$

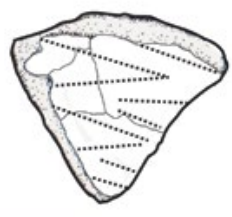

Figure 12.9: Selected examples of red-painted, circle-stamped and dentate-stamped decorated ceramics.

Source: Naszrullah Azis.

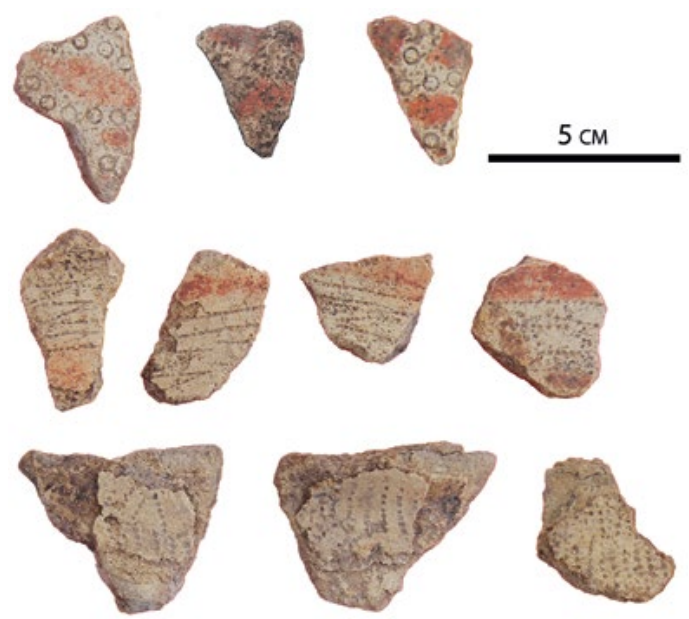

Figure 12.10: Selected examples of red-painted, circle-stamped and dentate-stamped decorated ceramics.

Source: Naszrullah Azis.
Pottery fragments with decoration are exceptionally rare and account for less than $1 \%$ of the assemblage (Figures 12.8-10). Decorations include dentate stamping, most commonly in straight or curved lines. Zigzag patterns and rhombic motifs are common. Single lines of circular bamboo stamps bordered by dentate-stamped lines have been recorded. There are two instances where bamboo stamps were noted, both as part of a joint composition with red paint, again with a rhombic pattern. Most of the decorated pottery shows red painting, including horizontal lines associated with dentate-stamped borders on several sherds. One sample showed white incrustation associated with dentate stamping, albeit it is unclear whether this is a weathering product or intentional addition of lime or other carbonate film. At this stage, identified incision is extremely rare as only one sherd with possible incision was found. Instances of rim-notching have been detected.

A red slip, which has substantially exfoliated, was frequently applied. Of the 1019 wall sherds analysed, $150(14.7 \%)$ retained red slip or red paint on the inside surface and 165 (16.2\%) on the outside. This high percentage (24.6\%, taking both inside and outside surfaces into account) of applied slip would be further enhanced by only considering the 611 sherds with non-eroded surfaces, which would result in $41 \%$ of the sample displaying red-slipped surfaces.

\section{Discussion}

The location of the Mansiri site follows a similar settlement pattern to the sites of the Karama valley, Kalumpang in West Sulawesi (van Heekeren 1957; Anggraeni et al. 2014), both being associated with main inland river systems. The distance from the coast along the river system of the Mansiri site is comparable with Pantara'an 1, whereas the sites at Minanga Sipakko and Kamassi are twice that distance. Mansiri appears to be slightly younger than the Neolithic deposits at Minanga Sipakko, which have been dated from c. $3500 \mathrm{cal} \mathrm{BP}$ ranging to $3000 \mathrm{cal} \mathrm{BP}$ 
(Anggraeni et al. 2014:745, Table 1). Anggraeni et al. (2014:746) state that the dates from Kamassi confirm that the transition to pottery making was completed by 1500 BC in the Karama valley at Minanga Sipakko; however, the Kamassi early dates derive from uncalibrated freshwater molluscs for which no local calibration curve was adopted (see Keaveney and Reimer (2012) and Philippsen (2013) for discussions of significant in-built ages in freshwater molluscs). The only published charcoal date for Kamassi suggests a later deposition at around 3175-2365 cal BP; however, this sample derives from higher levels than the freshwater mollusc dates. Similarities in the vertical distribution of different types of ceramics at Kamassi and Minanga Sipakko might indicate that the earlier dates at both sites are outliers and an initial transition to pottery use might have occurred a few hundred years later than inferred by Anggraeni et al. (2014). This is also reflected in the ceramics found at Mansiri, which show some similarities such as circular stamping with the pottery from Minanga Sipakko and Kamassi as well as those from Nagsabaran in Luzon (Hung et al. 2011). However, incisions that are common at these latter sites are virtually absent from Mansiri. The lack of incisions in association with missing curvy-linear decoration patterns, and rectangular, instead of circular or triangular stamping, also excludes a comparison with later Iron Age Sa-Huynh Kalanay ceramics (Solheim 2006).

Dentate stamped red-painted pottery is exceptionally rare in ISEA and its occurrence in a possible 3000-year-old site in North Sulawesi invites a comparison with Lapita assemblages in Near Oceania. A detailed analysis of the decoration is ongoing and will be presented at a later stage. Initial similarities between the Mansiri dentate-stamping, infilled and red-painted horizontal lines can be detected with middle Lapita assemblages from Vanuatu (Bedford 2006), but the Mansiri assemblage also shows significant differences from the highly ornate Lapita pottery, and so significant additional research is necessary to determine the nature of any connections.

The ambiguous status of the Mansiri radiocarbon dates is not unique for ISEA where the transition to the Neolithic is not very well dated. The earliest radiocarbon dates of initial pottery occurrence overlap at the 2 -sigma $95.4 \%$ confidence interval (Table 12.5). Almost none of these dates have been unambiguously accepted (for example, Spriggs 2003, 2007, 2011), particularly as only in rare cases in ISEA are local correction curves available for marine shell dates, and there are suggestions that the Neolithic transition might have occurred significantly later at each of the sites (Spriggs 2011; Carson and Kurashina 2012; Gaffney et al. 2015).

The hypothesis of a multi-directional backward and forward movement of goods and people has long been accepted further east in the Lapita distribution (Sheppard 2011), as exemplified by the flow of obsidian raw material (Green 1987; Sheppard 1993; Reepmeyer 2009). If we accept the later proposed dates for the appearance of Lapita in the Bismarck Archipelago (post-3200 cal BP; Specht et al. 2014) and the earlier age range of both Mansiri and the Karama valley sites (pre-3300 cal BP), then the Mansiri site might be viewed as an archaeological precursor to Lapita in ISEA, which would support earlier claims for direct connections between ISEA and the Western Pacific (Hung et al. 2011; Carson et al. 2014). This proposal, admittedly, is tenuous at best, and instead cultural influences in the reverse direction might have been at play.

However, the Lapita culture has been associated with highly mobile settlement patterns and a distinct maritime focus (Kirch 2000; Bedford et al. 2007). This adaptation does not accord well with the site location of Mansiri, which is as far away from the coast as the river system allows. Mansiri's location is unexplained at this stage, but would fit with the hypothesis that agricultural expansion followed an opportunistic pattern whereby arable land along large freshwater systems provided the primary targets for farming communities after an initial maritime spread of people and innovations (Bellwood 2005). 
Table 12.5: Summary of radiocarbon dates from selected early Neolithic sites in Island Southeast Asia.

\begin{tabular}{|c|c|c|c|c|c|}
\hline Region & Site & Lab-number & Age (calibrated) (95.4\%) & Shell dates & Reference \\
\hline Batanes Islands & Torongan Cave & \begin{tabular}{|l|} 
OZH 771 \\
Wk 14642
\end{tabular} & \begin{tabular}{|l}
$4510-4085$ cal BP \\
$3640-3452$ cal BP
\end{tabular} & & $\begin{array}{l}\text { Bellwood and Dizon } \\
2013\end{array}$ \\
\hline \multirow[t]{5}{*}{ Philippines } & Nagsabaran & \begin{tabular}{|l} 
WK-23397 \\
ANU 13016 \\
\end{tabular} & $\begin{array}{l}4517-4248 \text { cal BP } \\
3867-3697 \text { cal BP } \\
\end{array}$ & & Hung et al. 2011 \\
\hline & & NTU-3799 & & $\begin{array}{l}3450 \pm 40 \\
\text { uncalibrated }\end{array}$ & \\
\hline & Dimolit & GaK 2937 & 4815-3930 cal BP & & Peterson 1974 \\
\hline & Andarayan & N.G. & 3975-3380 cal BP & & Snow et al. 1986 \\
\hline & Edjek & Beta-1117 & 4421-3183 cal BP & & Hutterer 1982 \\
\hline \multirow[t]{2}{*}{ Talaud Islands } & $\begin{array}{l}\text { Leang Tuwo } \\
\text { Mane'e }\end{array}$ & ANU 1515 & 4821-4295 cal BP & & Bellwood 1976 \\
\hline & & ANU 10209 & & $\begin{array}{l}3690 \pm 70 \\
\text { uncalibrated }\end{array}$ & Tanudirjo 2001 \\
\hline \multirow[t]{2}{*}{ Sarawak } & Gua Sireh & $\begin{array}{l}\text { CAMS-725 } \\
\text { ANU } 7047\end{array}$ & $\begin{array}{l}4962-3581 \text { cal BP } \\
3921-2953 \text { cal BP }\end{array}$ & & $\begin{array}{l}\text { Datan and Bellwood } \\
1991\end{array}$ \\
\hline & Niah Cave & Gm-7204 & 3915-3410 cal BP & & Harrisson 1975 \\
\hline $\begin{array}{l}\text { Northern Papua } \\
\text { New Guinea }\end{array}$ & Wañelek & $\begin{array}{l}\text { Wk-22060 } \\
\text { GX-3326 }\end{array}$ & $\begin{array}{l}\text { 4146-3929 cal BP } \\
4226-3253 \text { cal BP }\end{array}$ & & Gaffney et al. 2015 \\
\hline
\end{tabular}

Source: See Reference column.

On the other hand, recent research has shown that social interaction between distant communities, including maritime transportation of raw materials in ISEA, can be traced back into the early Holocene period and might be associated with sea-level changes following the Late Glacial Maximum (Torrence and Swadling 2008; Neri et al. 2015; Pawlik et al. 2015). Considering the intensification of forest management evidenced at Niah Cave in Sabah (Barker et al. 2011) and early independent domestication of tuber crops in highland Papua New Guinea (Denham et al. 2003), it seems that the transition to pottery production and agricultural systems in ISEA was indeed complex and most likely a process that involved multiple migrations (Tumonggor et al. 2013), as well as staggered acceptance and discard of innovations by local communities over hundreds of years.

\section{Conclusions}

The new dentate-stamped ceramic site of Mansiri adds new information to the Neolithic transformations in ISEA. Radiocarbon and OSL dating show a level of uncertainty about the true age, and occupation length, of the site. Based on the acquired preliminary age determinations, we propose that there might be a Neolithic presence at the site of a few hundred years, which started just prior to $3000 \mathrm{cal} \mathrm{BP}$. At this stage of investigation, it might be tentatively inferred that the new-found pottery indicates links with the emergence of highly decorated dentate-stamped pottery of the Lapita Cultural Complex in the Bismarck Archipelago. However, the probability of a slightly later date of occupation at Mansiri makes it an unlikely precursor to Lapita. We propose here that the Mansiri site might show a backflow of ideas and people to the west, as would accord with the appearance of Kutau/Bao obsidian in ISEA at a similar time frame.

A more detailed analysis of the ceramics, combining results from the 2012-14 excavation and the 2015 excavation is forthcoming. These analyses will include typological assessment of rim shapes, a detailed study of the decorative motifs and technological analysis of manufacturing by examining direction of pores, geochemical and petrographic analysis of clay, temper and red-slip types, and compound specific radiocarbon analysis (CSRA) to obtain direct dates on the pottery manufacture. 


\section{Acknowledgements}

This research was funded through an ARC Discovery Early Career Researcher Award (DECRA, DE130100046) to Christian Reepmeyer.

\section{Author biographies}

Naszrullah Azis Manado Archaeology Office, Manado, North Sulawesi, Indonesia

Christian Reepmeyer College of Arts, Society and Education, Cairns Campus, James Cook University, Cairns, Australia; and Department of Archaeology and Natural History, School of Culture, History and Language, College of Asia and the Pacific, The Australian National University, Canberra, Australia

Geoffrey Clark Department of Archaeology and Natural History, School of Culture, History and Language, College of Asia and the Pacific, The Australian National University, Canberra, Australia

Sriwigati Manado Archaeology Office, Manado, North Sulawesi, Indonesia

Daud A. Tanudirjo Department of Archaeology, Gadjah Mada University, Yogyakarta, Indonesia

\section{References}

Aitken, M.J. 1985. Thermoluminescence Dating. London: Academic Press.

Anggraeni, T. Simanjuntak, P. Bellwood and P. Piper. 2014. Neolithic foundations in the Karama valley, West Sulawesi, Indonesia. Antiquity 88(341):740-756. doi.org/10.1017/S0003598X00050663 (accessed 5 June 2018).

Banerjee, D., A.S. Murray, L. Bøtter-Jensen and A. Lang. 2001. Equivalent dose estimation using a single aliquot of polymineral fine grains. Radiation Measurements 33(1):73-94. doi.org/10.1016/S13504487(00)00101-3 (accessed 5 June 2018).

Barker, G., L. Lloyd-Smith, H. Barton, F. Cole, C. Hunt, Philip J. Piper, R. Rabett, V. Paz and K. Szabó. 2011. Foraging-farming transitions at the Niah Caves, Sarawak, Borneo. Antiquity 85(328):492-509. doi.org/10.1017/S0003598X00067909 (accessed 5 June 2018).

Bedford, S. 2006. The Pacific's earliest painted pottery: An added layer of intrigue to the Lapita debate and beyond. Antiquity 80(309):544-557. doi.org/10.1017/S0003598X00094023 (accessed 5 June 2018).

Bedford, S., C. Sand and S.P. Connaughton. 2007. Oceanic Exploration: Lapita and Western Pacific Settlement. Canberra: ANU E Press.

Bellwood, P. 1976. Archaeological Research in Minahasa and the Talaud Islands, Northeastern Indonesia. Asian Perspectives 19(2):240-288.

Bellwood, P. 2005. First Farmers: The Origins of Agricultural Societies. Malden, MA: Blackwell Publishing.

Bellwood, P. and E. Dizon. 2013. The Chronology of Batanes prehistory. In P. Bellwood and E. Dizon (eds), 4000 Years of Migration and Cultural Exchange: The Archaeology of the Batanes Islands, Northern Philippines, pp.67-76. Terra Australis 40. Canberra: ANU E Press. doi.org/10.22459/TA40.12.2013.05 (accessed 5 June 2018). 
Bellwood, P. and P. Koon. 1989. 'Lapita colonists leave boats unburned!' The question of Lapita links with Island Southeast Asia. Antiquity 63(240):613-622. doi.org/10.1017/S0003598X00076572 (accessed 5 June 2018).

Bøtter-Jensen, L. 1988. The automated Risø TL dating reader system. International Journal of Radiation Applications and Instrumentation. Part D. Nuclear Tracks and Radiation Measurements 14(1):177-180. doi.org/10.1016/1359-0189(88)90060-X (accessed 5 June 2018).

Bøtter-Jensen, L. 1997. Luminescence techniques: Instrumentation and methods. Radiation Measurements 27(5-6):749-768. doi.org/10.1016/S1350-4487(97)00206-0 (accessed 5 June 2018).

Bøtter-Jensen, L., E. Bulur, G.A.T. Duller and A.S. Murray. 2000. Advances in luminescence instrument systems. Radiation Measurements 32(5-6):523-528. doi.org/10.1016/S1350-4487(00)00039-1 (accessed 5 June 2018).

Carson, M.T., H.-c. Hung, G. Summerhayes and P. Bellwood. 2014. The pottery trail from Southeast Asia to Remote Oceania. Journal of Coastal and Island Archaeology 8(1):17-36. doi.org/10.1080/15564894 .2012.726941 (accessed 5 June 2018).

Carson, M.T. and H. Kurashina. 2012. Re-envisioning long-distance Oceanic migration: Early dates in the Mariana Islands. World Archaeology 44(3):409-435. doi.org/10.1080/00438243.2012.727342 (accessed 5 June 2018).

Chia, S.M.S. 2003. The Prehistory of Bukit Tengkorak as a Major Pottery Making Site in Southeast Asia. Kota Kinabalu: Department of Sabah Museum.

Datan, I. and P. Bellwood. 1991. Recent Research at Gua Sireh (Serian) and Lubang Angin (Gunung Mulu National Park). Bulletin of The Indo-Pacific Prehistory Association 10:386-405. doi.org/10.7152/bippa. v10i0.11328 (accessed 5 June 2018).

Denham, T., C.B. Ramsey and J. Specht. 2012. Dating the appearance of Lapita pottery in the Bismarck Archipelago and its dispersal to Remote Oceania. Archaeology in Oceania 47(1):39-46. doi.org/10.1002/j.1834-4453.2012.tb00113.x (accessed 5 June 2018).

Denham, T.P., S.G. Haberle, C. Lentfer, R. Fullagar, J. Field, M. Therin, N. Porch and B. Winsborough. 2003. Origins of agriculture at Kuk Swamp in the Highlands of New Guinea. Science 301(5630):189193. doi.org/10.1126/science.1085255 (accessed 5 June 2018).

Fallon, S.J., L.K. Fifield and J.M. Chappell. 2010. The next chapter in radiocarbon dating at the Australian National University: Status report on the single stage AMS. Nuclear Instruments and Methods in Physics Research Section B: Beam Interactions with Materials and Atoms 268(7-8):898-901. doi.org/10.1016/ j.nimb.2009.10.059 (accessed 5 June 2018).

Gaffney, D., G.R. Summerhayes, A. Ford, J.M. Scott, T. Denham, J. Field and W.R. Dickinson. 2015. Earliest pottery on New Guinea Mainland reveals Austronesian influences in Highland environments 3000 years ago. PLoS ONE 10(9):e0134497. doi.org/10.1371/journal.pone.0134497 (accessed 5 June 2018).

Green, R.C. 1987. Obsidian results from the Lapita sites of the Reef/Santa Cruz Islands. In W.R. Ambrose and J.M.J. Mummery (eds), Archaeometry: Further Australasian studies, pp. 239-249. Canberra: Research School of Pacific and Asian Studies, The Australia National University.

Guérin, G., N. Mercier and G. Adamiec. 2011. Dose-rate conversion factors: Update. Ancient TL 29(1):5-8.

Harrisson, T. 1975. Early dates for 'seated' burials and burial matting at Niah Caves, Sarawak (Borneo). Asian Perspectives 18:161-165. 
Hung, H.-c., M.T. Carson, P. Bellwood, F.Z. Campos, P.J. Piper, E. Dizon, M.J.L.A. Bolunia, M. Oxenham and Z. Chi. 2011. The first settlement of Remote Oceania: The Philippines to the Marianas. Antiquity 85(329):909-926. doi.org/10.1017/S0003598X00068393 (accessed 5 June 2018).

Hutterer, K.L. 1982. Test excavations at the Edjek site (T V 161A) Tanjay, Negros Oriental. In K.L. Hutterer and W.K. Macdonald (eds), Houses built on scattered Poles: Prehistory and Ecology in Negros Oriental, Philippines, pp. 209-226. Cebu City: University of Santo Carlos.

Keaveney, E.M. and P.J. Reimer. 2012. Understanding the variability in freshwater radiocarbon reservoir offsets: a cautionary tale. Journal of Archaeological Science 39(5):1306-1316. doi.org/10.1016/j.jas. 2011.12.025 (accessed 5 June 2018).

Kirch, P.V. 2000. On the Road of the Winds: An Archaeological History of the Pacific Islands before European Contact. Berkeley, CA: University of California Press.

Mejdahl, V. 1979. Thermoluminescence dating: Beta-dose attenuation in quartz grains. Archaeometry 21(1):61-72. doi.org/10.1111/j.1475-4754.1979.tb00241.x (accessed 5 June 2018).

Murray, A.S. and J.M. Olley. 2002. Precision and accuracy in the Optically Stimulated Luminescence dating of sedimentary quartz: A status review. Geochronometria 21:1-16.

Murray, A.S. and A.G. Wintle. 2000. Luminescence dating of quartz using an improved singlealiquot regenerative-dose protocol. Radiation measurements 32(1):57-73. doi.org/10.1016/S13504487(99)00253-X (accessed 5 June 2018).

Neri, L.A.M., A.F. Pawlik, C. Reepmeyer, A.S.B. Mijares and V.J. Paz. 2015. Mobility of early islanders in the Philippines during the terminal Pleistocene/early Holocene boundary: pXRF-analysis of obsidian artefacts. Journal of Archaeological Science 61:149-157. doi.org/10.1016/j.jas.2015.05.005 (accessed 5 June 2018).

Pawlik, A.F., P.J. Piper, R.E. Wood, K.K.A. Lim, M.G.P.G. Faylona, A.S.B. Mijares and M. Porr. 2015. Shell tool technology in Island Southeast Asia: An early Middle Holocene Tridacna adze from Ilin Island, Mindoro, Philippines. Antiquity 89(344):292-308. doi.org/10.15184/aqy.2015.3 (accessed 5 June 2018).

Peterson, W. 1974. Summary report of two archaeological sites from north-eastern Luzon. Archaeology \& Physical Anthropology in Oceania 9(1):26-35.

Philippsen, B. 2013. The freshwater reservoir effect in radiocarbon dating. Heritage Science 1(1):24-43. doi.org/10.1186/2050-7445-1-24 (accessed 5 June 2018).

Prescott, J. and J.T. Hutton. 1994. Cosmic ray contributions to dose rates for luminescence and ESR dating: Large depths and long-term time variations. Radiation Measurements 23(2-3):497-500. doi.org/10.1016/1350-4487(94)90086-8 (accessed 5 June 2018).

Reepmeyer, C. 2009. Obsidian Sources and Distribution systems emanating from Gaua and Vanua Lava in the Banks Islands of Vanuatu. Unpublished PhD thesis, Centre for Asia and the Pacific, The Australian National University, Canberra.

Reepmeyer, C., M. Spriggs, Anggraeni, P. Lape, L. Neri, W.P. Ronquillo, T. Simanjuntak, G. Summerhayes, D. Tanudirjo and A. Tiauzon. 2011. Obsidian sources and distribution systems in Island Southeast Asia: New results and implications from geochemical research using LA-ICPMS. Journal of Archaeological Science 38(11):2995-3005. doi.org/10.1016/j.jas.2011.06.023 (accessed 5 June 2018).

Rhodes, E.J. 2011. Optically Stimulated Luminescence dating of sediments over the past 200,000 years. Annual Review of Earth and Planetary Sciences 39(1):461-488. doi.org/10.1146/annurev-earth040610-133425 (accessed 5 June 2018). 
Sheppard, P.J. 1993. Lapita lithics: trade/exchange and technology. A view from the Reefs/Santa Cruz. Archaeology in Oceania 28(3):121-137. doi.org/10.1002/j.1834-4453.1993.tb00303.x (accessed 5 June 2018).

Sheppard, P.J. 2011. Lapita colonization across the Near/Remote Oceania Boundary. Current Anthropology 52(6):799-840. doi.org/10.1086/662201 (accessed 5 June 2018).

Snow, B.E., R. Shutler, D.E. Nelson, J.S. Vogel and J.R. Southon. 1986. Evidence of early rice cultivation in the Philippines. Philippine Quarterly of Culture and Society 14(1):3-11.

Solheim, W.G. II. 2006. Archaeology and Culture in Southeast Asia: Unraveling the Nusantao. Manila: The University of the Philippines Press.

Specht, J., T. Denham, J. Goff and J.E. Terrell. 2014. Deconstructing the Lapita Cultural Complex in the Bismarck Archipelago. Journal of Archaeological Research 22(2):89-140. doi.org/10.1007/s10814-0139070-4 (accessed 5 June 2018).

Spriggs, M. 2003. Chronology of the Neolithic Transition in Island Southeast Asia and the Western Pacific: A View from 2003. The Review of Archaeology 24(2):57-80.

Spriggs, M. 2007. The Neolithic and Austronesian expansion within Island Southeast Asia and into the Pacific. In S. Chiu and C. Sand (eds), From Southeast Asia to the Pacific: Archaeological Perspectives on the Austronesian Expansion and the Lapita Cultural Complex, pp. 104-139. Taipei Academia Sinica: Research Center for Humanities and Social Sciences. doi.org/10.1017/S0003598X00067910 (accessed 5 June 2018).

Spriggs, M. 2011. Archaeology and the Austronesian expansion: Where are we now? Antiquity 85(328):510-528, doi.org/10.1017/S0003598X00067910 (accessed 5 June 2018).

Tanudirjo, D.A. 2001. Islands in Between: Prehistory of the Northeastern Indonesian Archipelago. Unpublished PhD thesis, School of Archaeology and Anthropology, The Australian National University, Canberra.

Torrence, R. and P. Swadling. 2008. Social networks and the spread of Lapita. Antiquity 82(317):600-616. doi.org/10.1017/S0003598X00097258 (accessed 5 June 2018).

Tumonggor, M.K., T.M. Karafet, B. Hallmark, J.S. Lansing, H. Sudoyo, M.F. Hammer and M.P. Cox. 2013. The Indonesian archipelago: An ancient genetic highway linking Asia and the Pacific. Journal of Human Genetics 58(3):165-173. doi.org/10.1038/jhg.2012.154 (accessed 5 June 2018).

van Heekeren, H.R. 1957. The Stone Age of Indonesia. Verhandelingen van het Koninklijk Instituut voor Taal-, Land- en Volkenkunde 21. The Hague: Martinus Nijhoff.

Wintle, A.G. and A.S. Murray. 2006. A review of quartz optically stimulated luminescence characteristics and their relevance in single-aliquot regeneration dating protocols. Radiation Measurements 41(4):369-391. doi.org/10.1016/j.radmeas.2005.11.001 (accessed 5 June 2018).

Zimmerman, D.W. 1971. Thermoluminescent dating using fine grains from pottery. Archaeometry 13(1):29-52. doi.org/10.1111/j.1475-4754.1971.tb00028.x (accessed 5 June 2018). 
This text is taken from The Archaeology of Sulawesi: Current Research on the Pleistocene to the Historic Period, edited by Sue O'Connor, David Bulbeck and Juliet Meyer, published 2018 by ANU Press, The Australian National University, Canberra, Australia.

doi.org/10.22459/TA48.11.2018.12 